\title{
Overcoming Rent by Using Rent: The Challenge of Development
}

\author{
Hartmut Elsenhans*
}

\begin{abstract}
The article tracks the current crises of development theory in the understanding of the differences in political economy of developed capitalism (rising mass incomes) and underdeveloped economies (labor surplus and rent). The challenge of rents consists in spontaneous tendencies of its wasteful use for blocking development, which do, however, not exclude its possible use for the elimination of marginality.

A convoy model of globalization with world wide full employment and an underconsumptionist model are distinguished. In the convoy model, an underdeveloped economy reaches full employment on the basis of devaluation. In the underconsumptionist model, devaluation-driven export-oriented industrialization does because of its too small impact not lead to the scarcity of average skilled labor. Leading industrialized countries react to the new competitiveness of catching-up economies through the implementation of wage restraint and industrial policies. Rent bounces back. Establishing a convoy model requires development policies characterized by an intelligent mix of rising mass incomes, reduced rents and devaluation-driven industrialization together with state support for investment.
\end{abstract}

\section{Introduction}

The article tracks the current crises of development theory in the understanding of the differences in political economy of developed capitalism and underdeveloped economies

* Universität Leipzig.

Korrespondenzanschrift:

Prof. Hartmut Elsenhans, Universität Leipzig, Institut für Politikwissenschaft, Burgstraße 2I, 04IO9 Leipzig, E-Mail: helsen@rz.uni-leipzig.de

Ersteinreichung des Artikels am 30.7.2003, endgültig akzeptiert am 20.1.2004

(C) InTERvention. Zeitschrift für Ökonomie, Jg. 1 (2004), H. 1, S. 87-115 
and presents a stylized model of capitalism under perfect competition. In developed market economies a high marginal product of labor leads to labor scarcity. As a result mass incomes rise and lead to the rising profitability of capacity increasing investment with total investment spending increasing eventually enabling profit as one category of surplus to displace rent as another category of surplus.

Underdeveloped economies are characterized by the simultaneous existence of surplus labor and a surplus of resources that can be appropriated as rents, because the marginal product is lower than the cost of subsistence of a laborer and his family. At the same time there is a surplus from more productive other labor, which cannot be appropriated in the form of profit for lack of investment spending. It is available as rent to be appropriated by non-economic political mechanisms. Rents are an obstacle to the coordination of a lean state, an autonomous civil society and a self-steering market economy, but they are at the same time a source of finance for overcoming underdevelopment. The challenge of rents consists in spontaneous tendencies of its wasteful use for blocking development, which do, however, not exclude its possible use for the elimination of marginality, if there is corresponding political will. Export-industrialization is a strategy, which more effectively eliminates marginality through the channeling of rents. Rent is used in export-industrialization to feed labor in export-oriented sectors transforming comparative advantages into cost competitiveness via devaluation.

The following article distinguishes between a convoy model of globalization and an underconsumptionist model. In the convoy model, an underdeveloped economy reaches full employment on the basis of devaluation. Unlimited devaluation becomes impossible. Labor scarcity emerges and transforms these economies into normal capitalist ones, which contribute to the expansion of world demand in line with their productivity increases. Devaluation-driven export-oriented industrialization may, however, have too small an impact of the employment in economies characterized by marginality, thus hindering realization of average skilled labor scarcity - the underconsumptionist model. These economies would increase global world production capacity without contributing to global world demand. Leading industrialized countries react to the new competitiveness of catching-up economies through the implementation of wage restraint and industrial policies. Rent bounces back.

Making globalization socially acceptable by transforming marginality-ridden economies into capitalist ones with a scarcity of labor requires development policies characterized by an intelligent mix of rising mass incomes, reduced rents and devaluation-driven industrialization together with state support for investment.

Establishing a convoy model of globalization and avoiding an underconsumptionist one, hence, the globalization of profit against the globalization of rent, requires social and economic reforms in the interest of the rural masses in the marginality-ridden economies. Certain aspects of the policy mix of simultaneously increasing mass incomes and market-driven investment are discussed. 


\section{Some aspects of the concept of rent}

A surplus of resources is defined as that part of the income disposable in an economy, which is not used for the compensation of labor. Labor offers its services at a rate corresponding to its marginal product on labor markets characterized by perfect competition and generalized access of labor to education and training according to its fundamental physical and mental capabilities. The surplus of resources can be divided into three categories using as distinguishing critieria the mechanisms of appropriation, control and utilization. Profit depends in a double way on investment. The total spending on profit determines the total amount, which all entrepreneurs, as a class of economic actors, can earn on totally competitive markets with labor not saving parts of their incomes and the government sector and foreign trade being balanced (Kalecki I97I: I3). The share of a particular entrepreneur in this amount depends on his capacity to produce goods and services, which are in demand and economically efficient in comparison to his competitors. Total profit depends on the expectations on the growth in the demand for products produced with investment goods. Individual profit is subject to control through competition. Tax is that part of the surplus, which is appropriated and spent by a centralized structure, the state, and subject to political control, being democratic or non-democratic. Rent is the part of the profit, which is appropriated by decentralized institutions on the basis of non-market instruments, such as naturally or politically created monopolies. In the case of rent, there are no centralized institutions, which can be made accountable.

If economies enjoy monopolies in their export sectors, taxes may be assimilated to rents, because their appropriation does not require the consent of those, who have to pay. Their origin from exports does not empower local political groups in their quality as taxpayers. They are not subject to control by the market or to the control of whatsoever centralized structures, as implied by the territorially defined lawmaking capacity of the sovereign state. When such external rents become important, the dependence of the state from taxes paid by its territorially confined constituencies decreases. It becomes a rentier state (Schmid 199I; Beblawi/Luciani 1987; Yates 1996). The separation between tax and rent is increasingly difficult due to the fragmentation of the state (Neale 1957: 23I), as described in my theory of bureaucratic development societies, which are dominated by state classes (Elsenhans 1996) leading to the creation of the oligarchic or patrimonial state (Dornbos 1990; Bayart 1989; Joseph 1987; Bratton/Van de Walle 1994). Control of the use of rents depends on the capacity of social groups to have access to the rent. In fragmented structures this leads to the spending of rents on the increasing political power.

\section{The crisis of economic development as a paradigm crisis}

Theories of economic development do not fit into mainstream (neoclassical) economics. They are invariably based on the assumption that something has to be added to the mar- 
ket mechanism for the market to produce growth and equity, which would otherwise not result from the market alone (Rosenstein-Rodan 1943). There have to be non-market elements and multidisciplinarity. In their more conservative forms, they trace market failure to attitudes they consider to be determined by social structure or cultural heritage (Rostow 197I: I13; Hohorst 1973; Germani 1966: 25; Harrison 1985: I66; Heintz 1969: I64; Lipset 1986; Hagen 1964; MacClelland/Winter 1969; Apter 1969). In their more radical versions, they focus on power structures resulting from the political set-up, which allow "elites" to block competition on the market (Albertini 1967: 67; Bauer 198I: 35; Benetti I974: 224).

Economic development is in a double crisis. There is a crisis of the strategies advocated by traditional theories of development (Chakravarty 1987; Pierterse 1996), such as modernization theory or dependencia (Palma 1978; Ramos 1974; O’Brien 1975). The overall approach of establishing the foundations for self-sustained economic growth with trickle-down effects on the standard of living of the mass of the population did not fulfill its promises (Adelman 200I: I04; Hirschman 1971: 44; Behrendt I97I: 402; Meier I984; Hemmer 1978: 252-254). Second, there is a crisis of new development thinking. Where economic development did occur, such as in the East Asian tiger nations, mainstream economics appropriated this as proof for the dynamics of the capitalist world market, making a specific theory of economic development seem superfluous (Lal I983; Toye 1987). However, a closer look at these success stories has shown that they were equally embedded in social and political structures that favored redistribution (shared growth) (Page 1993: 157) and sectoral industrial policies, using political mechanisms to deliberately "get prices wrong" (Amsden 1989: 139). This approach is now less popular, as the intervention of well-meaning NGOs has introduced a discourse on the necessary empowerment of the poor. The consequences of this empowerment for the economic basis are, however, rarely discussed (Hofmann 200I; Sen I98I).

In order to reduce the cacophony of current contributions, it seems useful to focus on the basic assumptions used by neoclassical economics as the basis for its predictions about unfettered markets - that "getting your prices right" will lead to full employment equilibria with more or less natural growth rates (Mathur I99I: 230). The central argument of neoclassical economics is, in my view, its modelling of the clearing process on labor markets and the subsequent use of enterprise earnings for investment (Say I972: I40 ff.). All available surplus is spent on investment into competitive machinery and other equipment, since available surpluses would otherwise bear no interest. Provided that labor is cheap enough to produce a surplus for the investor, the economy has to reach full employment, as the owner of money will always prefer to earn some money rather than no money. As all income earned is spent on products and, ultimately, on labor, the economy cannot avoid full employment. Due to full employment, labor automatically shares the fruits of productivity growth. Any innovator with an above-average rate of profit will be eager to draw scarce labor from less lucrative occupations.

This implies a tendency towards the uniformization of capital and labor prices, which enables the economy to respond flexibly to any change in demand and potentially 
to external shocks as well. In a capitalist economy, changes in demand induce enterprises in a branch with above-average increases in demand and/or in productivity to initially invest their above-average profits in their own branch. With at least some capital mobility and/or accessibility of technical solutions used in this branch, then changes in demand attract additional capital from other branches. Both types of investment growth in the branch with above-average demand expansion requires labor as a complementary factor of production. Additional labor is attracted by higher wages. With full employment (but only under these conditions), higher wages prevent technically less performing production branches from maintaining their levels of employment. If they cannot increase productivity, they have to either reduce employment or increase prices or both. This will result together with declining prices for the technically dynamic branches (following the gradual saturation of their markets) in the equalization of productivity levels measured not in terms of quantity, but in sales. The result is an equalizing of productivity based on earnings despite differences in technical progress in different technical branches. Productivity therefore converges in all branches through factor movements and price changes until marginal factor costs equal marginal outputs and marginal utility costs equal marginal unit prices. The flexibility and gradualism of capitalism, which constitute an important aspect of its allocative efficiency, are themselves a consequence of the full-employment tendency at any given level of economic development.

Keynesians and dependencia authors agree that in the absence of full employment, the tendency to limit this competition-based process increases with general unemployment, the non-innovative branches will not attempt to sustain their workforce through wage increases. Korean authors have identified two periods of their development: until the I970's the price of labor rose only for skilled labor as long as there was underdevelopment, wages increased for all labor only when full employment was reached (Bai I982: I35). Similarly, Aitken/Hanison/Lipsey (1996) observe a general increase in wages paid by multinational companies in full-employment regions, but only contributing to sectorally limited wage increases in underdeveloped countries.

In order to tackle the problem of potential multiple equilibria (Grabowski 2000: 247; Nelson 1956; Hayami 1997: 24), some of which are characterized by unemployment, Keynesians take into account the "active role of money". The banking system can easily create money, if there are investors who are ready to contract debts. Money creation has limits and applies only to situations, where there is idle labor. The purpose of Keynesian state interventionism is therefore to bring the economy back to a neoclassical mode of operation by creating full employment, which then launches private investment (Keynes I973: I3I). Thus, neither Keynesianism nor post-Keynesianism involves a theory of state failure. Keynes shares the neoclassical conviction concerning the superiority of a market economy and its allocative efficiency, but not the belief that the economy will automatically approach full employment, if wages are only low enough. He therefore admitted that idle capacity may exist.

In typical underdeveloped economies there is, however, no idle capacity in production to be brought onstream in the short-term by simply injecting money into the 
economy, especially because there are often no capacities in investment-goods production, which could deliver the machinery necessary to create jobs in line with demand on the consumption-goods market. With underdevelopment characterized by the absence of investment opportunities, narrow markets, because of poverty and a diversified demand to be supplied by high-cost items due to low production runs, investment is limited and - because of limited demand - investment goods are not locally produced, since cheaper sources of supply exist in most cases. In this case, profit earned under competition cannot emerge as an important source of income as multiplier effects remain limited.

\section{The social implications of full employment: The autonomy of civil society and a lean state}

For neoclassical economics, rising real wages are an inevitable consequence of growth. For post-Keynesians, they are its very condition (Elsenhans 1983). Despite this opposition, the two views converge in associating capitalist growth with rising mass incomes. This is relevant for a variety of aspects of capitalist societies, which I can only mention here without greater detail. The lean capitalist state is the result of this tendency towards full employment. If capitalists increase investment, labor becomes scarce and can impose higher wages. By expanding consumption, labor increases the possibilities for profitable investment. The two social classes of a capitalist system empower themselves in a ping-pong effect without any consultation simply by pursuing their most selfish interests (Elsenhans 1999a). Neither class has a need for the redistributive state of the tributary pre-capitalist modes of production. As a result, the state's role is reduced to producing public goods and a legal framework for the exchange economy. Society allows limiting the network of social interactions to economic exchange (Tönnies 1935: 40 ff.), thus making communal ties a matter of choice and enabling the emergence of the bourgeois individual and Marx's doubly free worker who is exploited but not marginalized.

With both classes of a capitalist society earning their necessary incomes without state intervention in the day-to-day operation of the economy, these classes are free to create interest-based associations, which fulfill the needs once attended to by primordial communities within pre-capitalist structures in a decentralized manner. These associations are normally referred to as civil society. Non-state organizations also existed within pre-capitalist structures, as the state was not able to extend its sphere of influence to the individual communities on its territory. However, if such associations wanted to achieve goals beyond a purely local nature, they had to address themselves to the state, since the state had discretionary power over all types of property rights. Even long-distance trading companies had to enter into clientelistic forms of dependency with the state. It is the very absence of clientelistic relations with the state which characterizes the autonomy of civil society. 


\section{A stylized model of underdevelopment}

Underdeveloped economies are characterized by structural unemployment and are therefore radically different from developed ones. From the very beginning of development theory, authors such as Georgescu-Roegen (1960) had argued that structural unemployment is caused by the marginal product of labor being lower than its costs of reproduction, i.e., the necessary costs for the survival of a laborer and his nuclear family (Sen 1966; Dandekar 1962; Minami 1966) output per capita may be higher than this marginal product. In a society, where average product is lower than the costs of reproduction of labor, either part of the population has to migrate or has to die through famine.

A high average product per capita and a low marginal product of labor can coexist, if there is a branch of production with decreasing returns, whose decline in productivity cannot be compensated by rises in productivity in other branches, because the share of this branch in national income is too large. If ecological costs are not taken into account, any technical solution in industry can be copied and reproduced. The marginal product of labor in industry cannot decrease indefinitely. In primary production, such as agriculture or raw-materials production, the marginal product may, however, decrease indefinitely, because the natural conditions of production may worsen with the expansion of production, despite technical progress.

Underdeveloped economies are characterized by low per-capita incomes and low mass consumption. The share of food in total consumption of the great majority of households is high, normally not less than fifty percent, but rarely more than seventy percent (Khan 1963; Ray 2000), since there is a minimum amount of non-food consumption in the form of shelter, clothing, household equipment and miscellaneous items at fairly equal shares, most of which are produced locally by the small-scale »informal« sector.

Agricultural production is subject to diminishing returns, the more so the lower is the level of technical development, because solutions to agricultural shortage depend on the availability of fertile land. Agricultural production increases with the number of workers engaged with the effect that demographic growth itself may contribute to economic growth. Beyond a certain level, however, the increase in production will be lower than the rate of increase of agricultural workers, if there is no technical improvement. The marginal product per additional worker will eventually fall below the additional costs of this worker (the costs of reproduction of this worker and his family) (Elsenhans 1994; 1995). With population growth beyond this level there is marginal labor, that is, labor whose marginal product is lower than its costs of reproduction. Beyond this level there is a surplus of able-bodied workers and, hence, the constant pressure of able-bodied workers on the labor market.

At the same time there may be a significant agricultural surplus, especially in the so-called "hydraulic societies" such as the old Chinese Empires, the Gangetic Valley, Vietnam, Mesopotamia and Egypt (Wittfogel I93I), Marx's Asiatic mode of production (Marx 2000: 376), which Wittfogel described later as oriental despotism (Wittfogel 1957). Even if the centralization of surplus appropriation is low during the dynastic downturn 
of the state (Reischauer/Fairbank 1960: II7; Wakeman 1977: 204 ff.; Skinner 1971: 273; Usher 1989: I044; Ibn Khaldûn 1967: 570-57I, 599-606), the owners of land can appropriate the surplus from their land and are not exposed to competition, if they return to the closed-domain economy of their agricultural lands. They may opt for the improvement of agricultural methods, but they do not have to do so, as described by Adam Smith (1976: 439) in his description of pre-capitalist Europe.

The only mechanism that must be explained in order to demonstrate that neoclassical economics applies only to economies, which have already undergone a successful transition to capitalism, is why such a surplus of able-bodied labor can emerge without these additional and superfluous people simply starving. The poor have no choice, but to work in lottery-type labor markets, where their chances of survival increase as the larger their solidarity group becomes. The history of the peasant populations of all pre-modern empires can be described on the basis of this behavioral norm (e.g. China, see Chao 1986). Unable to provide higher economic yields on a given parcel of land relative to their competitors, the poor will complement their labor services in agriculture by offering supplementary services such as veneration or special forms of obedience, in other words, by entering into relations of dependence and clientelism, even at levels of economic development characteristic of "primitive" communities. Those in control of land have an equal interest in the demographic growth of the poor. They are engaged in a struggle for relative shares in the access to rent-generating (political) assets. The number of clients is an asset in this struggle, as it contributes to their capacity to use force against rivals.

\section{The inevitable politicization of economics in marginality-ridden economies}

The political dimension in theories of economic development has its basis in the absence of the empowerment of labor on the labor market through its scarcity and the secondbest option of the poor in entering into networks of patronage, which becomes possible economically if the rich can block competition on the market by imposing market distortions through political struggles.

The mechanisms leading to such a power-based structure can already be observed in relatively egalitarian and even state-less societies in parts of Africa (Rodegem I974: 289; Oki 1984: 50) or Asia (Leach 1954: 23I). Surplus accumulated for periods of famines, etc. is regularly depleted in ceremonial activities. Suppose that marginality emerges due to demographic growth. Those, who, because of land scarcity or simply because of unequal access to land, may become marginal laborers, naturally insist on the necessity of using the accumulated surplus for subsistence purposes and will offer their services to the prestigious and newly powerful. From its original role as emergency provisions, the surplus becomes the basis for the creation of a hierarchically organized power structure with a ruling class and an exploited class. Due to diminishing returns in agriculture, the 
latter depends on the ruling class for the redistribution of resources, lawmaking and also on investment in irrigation systems, as in large parts of Asia and Latin America.

The horizontal organization of class interests is difficult in such a set-up. Social conflict is not focused on issues of distribution between social classes, but on preferential access to the rents controlled by the powerful. This access is based on connections, religious affinities, family ties and a variety of struggles to gain respectability. The issues and the criteria for victory in these struggles require that the poor do not cling to solidarity, but instead try to show that each individual or each group (in this case with terrible in-group fighting) is better than the rest. Issues of distribution could promote economic growth by expanding markets and increasing social cohesion. They could lead to a social structure, where relatively uncomplicated divisions between rather homogeneous blocks would prevail. Conflicts over the respectability of the poor (and the rich) will depend on complex processes of reciprocal and in-group evaluations, which can be conveniently described as power games, often observable in the form of face-saving.

The result is an overburdening of the political system combined with its low capacity to resolve conflicts. Due to rent, there is a culture of dependency instead of solidarity among the lower classes. At the top, rentiers seek to boost their prestige - their (assumed) capacity to mobilize power and financial resources in order to impose their views in the struggle over access to rent-generating assets. A centralized political structure, which I refer to as the state class, is made up of rivaling members, or segments of the rent-appropriating class, who constantly quarrel over their relative status. They wield financial resources, power, influence and prestige (Elsenhans 1996: 275-322). Communication is hindered due to this permanent struggle.

Under a situation of perfect competition businessmen in a capitalist economy have to accept the results of the anonymous market, even if these are unpleasant. If they refuse the information the market delivers, they will lose their financial resources. In a non-capitalist rentier society, economic results can be influenced by the access to rents, hence, by the capacity to mobilize political support. This depends on the capability to distort information. As a result, the images members of the ruling class create about themselves in order to forge alliances and to intimidate rivals is more important than facts. The flow of accurate information in a rentier society is therefore restricted and priority is given to face-saving. The ruling class looses contact to economic reality. It was only after the death of Boumedienne that the extreme inefficiency of planned investment in relation to production targets in Algeria (1979) was revealed (MPAT 1980). The tale about the "Emperor's new clothes« nicely describes this mechanism of collusion in information distortion. 


\section{The difficult transition from marginality-ridden underdeveloped economies to capitalist economies}

Technical progress will not per se allow the eradication of the rent-cum-marginality situation. Technical progress in the manufacturing of luxuries (more, but mostly »better", more conspicuous luxuries) will benefit the ruling "elite", as has been the case in the various attempts to catch up with the industrializing West since the beginning of the nineteenth century. Technical progress in non-agricultural mass-consumption goods will reduce the cost of labor, due to the higher initial share of such products in the costs of reproduction of a laborer, but only with limited effects on employment. Technical progress in agriculture may either increase the productivity of already active labor (e.g., through mechanization) or increase marginal product (e.g., through the irrigation of desert areas), although the introduction of agricultural innovation will normally result in a combination of both. If only the product of that labor, which is already employed, increases, then the rent of the land-owning class will increase. Only agricultural progress, which increases the marginal product will effectively increase the productively active share of the population, which produces a surplus and can possibly threaten to withdraw from economic activity.

Moreover, in the marginality-cum-rent situation there is limited interest in investment, as purchasing power for non-food items is concentrated in the hands of the rentier class, which consumes diversified, high-quality luxuries produced by craftsmen in small production batches. Machinery is used mostly in the production (and transport) of intermediate goods. In short, there is rarely a lack of financial resources, but, rather, a lack of investment opportunities (Bagchi 1972: 29). The inferior character of the machine-made leading products of the Industrial Revolution in England has often been highlighted (Nef I958: I2I f.). The profile of today's informal sectors in many developing countries is just another example.

The break up of a marginality-ridden system depends either on the empowerment of labor or a shift in the interests of the surplus-appropriating class. A scarcity of surplusproducing workers reduces the amount of rent. A rise in the threshold of marginality increases the potential employment of workers on the basis of at least subsistence wages. Rising costs of labor and expanding outlets make investment profitable. Increasing shares of a possibly reduced surplus are then used for economic improvement and profit replaces rent.

A pre-capitalist society can function as long as it produces more than its population can consume. A capitalist society can experience economic growth - the condition for its continued existence - only if its marginal labor also produces more than the basic needs of a laborer and his family. With decreasing returns, the level of marginal productivity in a pre-capitalist society can be lower than the level required for the continued existence of a market-based capitalist one, even if its average productivity is higher. 


\section{Dependencia as the result of rent}

The character of technical progress itself has to lead to the comparative disadvantage of backward economies in most modern machinery production. An innovator can introduce new machinery onto the market on the basis of an improved performance-cost ratio in relation to previous models. Under conditions of competition from other imitators, who can produce similar machinery if the basic characteristics of the new production process are known, the innovator cannot escape price competition. All imitators and innovators have to earn enough to cover their costs of production as well as the costs of developing and imitating future machinery. They must therefore earn the costs of maintaining their learning capacity. By producing the most advanced machinery, the leading imitators and innovators earn enough money to constantly acquire the most advanced knowledge (Posner 196I). The performance-cost ratio of new equipment improves. The user of the new machinery can reduce his costs of production because of cheaper equipment, in principle, in all economies. It has been shown, especially for Mexico, that productivity in Technically Backward Countries (TBCs) is higher in capital-intensive plants with imported equipment than in labor-intensive plants, even if these labor-intensive plants do not employ high-skilled labor (Boatler 1974: 838; Clague 1967: 492; 1991: 526). This is consistent with post-Keynesian (Denison 1967) and recent versions of neoclassical endogenous growth theory, which stress the importance of disembodied factors of technical progress (Fagerberg 2000; Lucas 1988; Collins/Bosworth 1996; Ark/Pilat 1993). The disembodied character of these highly debated factors in technical progress (besides accumulation of physical capital) is important. These factors do not appear as direct costs of production. They have been acquired through skill creation and learning during previous production processes. The leading economy has acquired them in a path dependent manner as a byproduct of production processes, which delivered affordable goods at profitable prices. Later on, they do not cause new costs. The catching-up economy has still to pay for these costs, as it has not acquired the level of skills and knowledge of the leading country. The disembodied factors are especially important for the invention and design of new investment goods. As long as knowledge and skills are internationally immobile, because they are qualities of human labor, these disembodied factors imply the comparative disadvantage of TBCs in technology production

Without local equipment production, innovation and the herd-like concentration of investment in »boom" phases - typical forms of labor empowerment in capitalist countries - do not lead to rising employment in the TBCs. The at least cyclical period of labor scarcity in capitalist countries had a pronounced influence on the development of productivity-enhancing forms of class struggle (Geary 198I: 38; Brown 1982: I7I). Moreover, in developed capitalist societies of the nineteenth century, labor was able to defend its real-wage position politically because prices declined in periods of recession more rapidly than wages (Bernanke/Carey 1996; Habakkuk 1972: 275).

Dependency induces inflexibility. The long-term specialization on raw materials is just a special case of this, and the one most often quoted. It was originally accom- 
panied by initially high export earnings, which discouraged industrial diversification and encouraged the import of luxuries and technologies, described largely in the effects of Dutch disease (Corden/Neary 1982; Auty 1994; Kamas 1986; Allub 1983). Dutch disease is the mirror-like counter-model of declining terms of trade, as already described by Singer in stating the problematic of deteriorating terms of trade. By characterizing this mechanism as the secular decline in the terms of trade, Singer (1950: 482) warned that

"Good prices for primary products, especially when coupled with increasing quantities being sold, give underdeveloped countries the necessary means for importing capital goods and financing their own individual development, yet at the same time they eliminate the incentive to do so«.

The critique of early development theory on deteriorating terms of trade as the cause of underdevelopment argues that the root cause of lacking diversification is the lack of financial resources, because of deteriorating terms of trade, a form of exploitation defined as the transfer of capital from underdeveloped economies, which is no longer available for investment. The empirical objections to the decline of the terms of trade do not matter here. A capitalist economy benefits from falling terms of trade, as demonstrated by the recent export offensive of "Euroland « The importance given to the terms of trade in the light of the deindustrialization effects of Dutch disease highlights the importance of rent in dependencia-based proposals for overcoming underdevelopment. Suppose that an economy is not characterized by the convergence of productivity according to branches, but by low productivity in investment goods and basic wage goods production in comparison to a highly productive export sector (raw materials), which until recently has fetched reasonable process on the world market. Deteriorating terms of trade reduce the import capacity of such an economy. However, the deterioration of the terms of trade may not be dramatic enough to launch new branches of production, either import substituting ones or new export products, as the traditional export sector may still yield better export earnings than the new branches due to their very low productivity. Such an economy may be called import dependent. It does not react flexibly to deteriorating terms of trade by diversifying and still has to suffer from a declining capacity to import goods.

There are two possibilities to react to this challenge Rent appropriation allows to subsidize not yet profitable import substitution. Further deteriorating terms of trade allows new production lines become competitive.

As long as the terms of trade do not decline so dramatically eventually eliminating rents, the ruling class with its import dependency will shy away from devaluation. It will try an import substituting industrialization strategy. This strategy consists in taxing traditional exports in order to appropriate international currencies from which imports also of investment goods can be financed. These new industries are initially not competitive with world production and require protection. The taxing of traditional exports is possible, if and as long as their price contains a rent element, as otherwise the earnings will not be large enough to keep labor and capital from leaving these export branches. 
The direct or indirect taxing of raw material exports has been a major instrument for state-led industrialization since the Great Depression in the I930s (Bauer/Yamey I968: I53; Falola I996: 4Iff.; Goode 1984: I89). However, as such rents were limited, the lack of employment (Bruton 1968; Baer/Hervé 1966; Sanchez Ayuso 1972) precluded the expansion of the internal mass market also due to the labor saving character of the technology available on the world market (Singer 1975: 378), and went with a highly skewed income distribution no longer only between rich and poor, but also between those with formal employment in a protected industrial sector and the rest of the economy, often called informal sector. A social structure emerged, which differed decisively from capitalism, because of the absence of competition for the rich and the absence of the empowerment of the poor. The necessity of using rents for diversification implied increasingly centralized mechanisms of rent appropriation, which I have described as the state classes, which at least ideologically were committed to economic development on the basis of state intervention in investment, employment and income distribution. This structure could be maintained as long differential rents in mineral production (e.g. the oil countries, but also copper countries) and consumer rents in agricultural products (via cocoa and coffee marketing boards) (Bauer I98I: 50; Marcussen 1983: 7) were available and gave some plausibility to the expected results of import substituting industrialization, further as long as the state classes were able to maintain some coherence in the management of the rent.

Historically, scarce financial resources were used extremely inefficiently, so that ultimately these state classes had to accept a greater opening of their economies and created a new dependent relationship with international business and financial institutions. They would have been able to avoid this result, if they had not believed the illusion that by using rents they would be able to catch up to the leading industrialized countries without changing the internal social structure.

Dependencia is therefore the result of the wealth of the dominating class (Hiemenz 1989: 6ff.), which keeps it from being forced by the exploited and marginal classes to use rent for employment creation and economic diversification (Mahon 1992). The halt in the accumulation of rent, which had been an implicit demand stated by the dependencia theory, opened up the necessity of preceding to the second alternative in reacting to deteriorating terms of trade: accepting a further deterioration in order to become competitive with new products on the world market. Again this strategy is one based on rent.

\section{Export-oriented industrialization and the globalization issue}

Export-led industrialization in East and Southeast Asia was based on rents intelligently mobilized for employment creation. Newly industrializing economies have not become competitive on the basis of new comparative advantage or new possibilities of lowering their real wages. Instead they have become competitive on the basis of new possibilities 
of transforming already existing, perhaps decade-old, comparative advantages. There may be economies that are technically inferior in every product, but it is impossible that they are equally backward in all products. In other words, they will always have comparative advantage in some line of production.

Comparative advantage, however, has to be transformed into cost competitiveness through the adjustment of price levels between two economies, either through movements of bullion or adjustment of currency exchange rates, in case of balance of trade deficits. An economy with an external deficit does not become cost competitive in the production of a specific good, because it has a comparative advantage. Instead it has to adjust its local cost level to international prices until it sells enough to avoid balance of payments deficits. Obviously it becomes cost competitive first in the production of those tradables, where its backwardness is lowest in comparison to the leading exporters on the world market, i.e. where it has a comparative advantage.

Underdeveloped economies become capable of devaluation, because of their success in developing local food production. An economy, which is self-sufficient in food and has a small and medium-sized industrial sector producing mass consumption goods can in principle accept any rate of devaluation. The currency parities of the successful countries specializing in export-oriented manufacturing do not reflect purchasing parities, but are actually much lower. Workers in export sectors can in the local economy buy up to ten times (Chen et al. 1994) as much with their wages as compared to the purchasing power of their wages on the world market. The often quoted wage-cost differentials between Technically Advanced Countries (TACs) and the TBCs of the Third World stand at around 50:I and demonstrate that purchasing-power parity cannot exist, since nobody could survive on one-fiftieth of an American industrial worker's salary, if he had to pay American prices (Lafay 1995; Guillaumon-Jeanneney/Hua 1996).

Successful devaluation for a country engaging in export-led industrialization implies rates of devaluation, where local factors of production employed in export production cannot reproduce themselves from the earnings of the export sector. Somebody has to produce the additional supply of goods. This can only be a local sector of production. Given the mix of household expenditures of still poor export workers in underdeveloped economies, these additional supplies have to consist of food, some simple industrial products that can be produced by the small and medium-scale industry (informal sector), and some modern, albeit relatively simple products like refrigerators, TV sets, scooters or basic automobiles. The higher the local content of these industrial products, the more the expansion of their production depends only on the availability of a surplus of food.

The degree of devaluation accessible for transforming comparative advantage into cost competitiveness depends on the capacity of an economy to feed workers in the export sector from local wage-goods production. Underdeveloped economies become capable of devaluation, because of their success in developing local food production, and are forced to devalue due to the disappearance of raw-material rents.

That devaluation-driven export-oriented industrialization has its basis in rent becomes apparent by tracking the circulation of this rent. The rent is produced as a surplus 
of agriculture. In its physical form it is distributed to the additional workers in the export sector. Its value accrues, in part, to the additional export workers, but also partly to consumers in the TACs enjoying improved terms of trade.

Devaluation driven export-oriented industrialization therefore resembles import substituting industrialization. In the case of a pure reliance on the devaluation for achieving price competitiveness on the world market, the rent is channeled into cheapening the international cost of local labor in order to make this labor cheap for foreign investors and local exporters, whereas import substituting industrialization directly subsidizes investors. Any government engaging in such a strategy will limit the loss of foreign exchange resources due to devaluation by following industrial policies. When Korea was faced with a more and more price-inelastic demand for textiles in the 1970s, it blocked the imports of textile machinery (Mytelka 1986: 258). Textile exporters had to turn to local small and medium-sized industry for their machinery. They were certainly better extension agents than non-entrepreneurial development agencies. A similar effect could have been achieved by taxing textile exports, much like an oil-exporting or a coffee-exporting country taxes exports in the case of low price elasticity, and installing a promotional agency for textile machinery. The difference between the Korean solution (and similar strategies in Singapore (Holtgrave 1987: 70-8I; Rieger 1991: 18; Haggard 1983: 283) and these more obvious strategies of rent appropriation and allocation is the administrative leanness found in the Korean case and not its politico-economic structure. Thus, the Asian miracle is based on the skillful spending of rents (Khan 2000), although the process of rent channeling was not always as successful and efficient as in the quoted example, as the later Korean crisis shows (Rhee 1994: 232-234). Ever since the Asian crisis, the literature is abound with comments on the structures of "crony" capitalism in the successful exportoriented industrializing countries of East Asia, hence its rent-based character (Baer et al. 1999: 1743; Grabowski 1999: 173).

\section{Io. The rent bounces back}

There is a benign and a malignant case for devaluation-driven growth. In the benign case, full employment is achieved. With full employment due to employment increases in the export sector, further devaluation will lead to scarcity of labor, wage increases, and the expansion of the internal market. The capitalist growth mechanism is transferred. Further attempts to solve the employment problem by means of export surpluses will lead to imported inflation and increasing export prices. With persistent unemployment, any sectoral improvement in productivity will only lead to lower prices on the world market, and any increase in the surplus of food production to further devaluation. There are numerous countries, which can devalue without achieving full employment. They will be prepared to recklessly depreciate the foreign value of their currencies to achieve at least small amounts of additional employment. 
At the end of the nineteenth century only economies characterized by labor scarcity due to tendential full employment were competitive in price and income-elastic products, basically in manufactures. Suppose that an innovation occurs in one of these economies, which we will refer to as an innovative economy. Its price level appreciates, because of a surplus in its balance of trade (inflow of bullion or rising exchange rate). The less innovative economy with full-employment loses competitiveness in the branch, where innovation occurred in the more innovative economy. If the lag in productivity in other (non-innovative) branches of the less innovative economy is low in comparison to the leading economy, the general decrease in its price level in relation to the innovative economy allows it to increase exports of non-innovative products. It suffers from a decline in terms of trade, but not from major unemployment. Moreover, the less innovative economy cannot overtake the leading economy on the basis of a massive decline of its price level or exchange rate, as it rapidly launches exports in non-innovative goods. I have called this pattern of globalization a convoy model of globalization (Elsenhans 1999b). The convoy model never created political anxieties and was even accompanied by the rise of the welfare state in the industrialized West.

The convoy model implies one specific limit to devaluation: the high productivity of the full-employment TBC in non-innovative products. High productivity in backward products across capitalist economies may suggest cultural homogeneity. Without denying a tendency towards cultural homogeneity (since full employment creates similar habits of thinking among the working class and, consequently, also among those who lose their privileges), it is clear that the basis of this homogeneity rests in full employment abolishing the structural heterogeneity found in dependencia theory (Nohlen/Sturm 1982). Full employment imposes interbranch convergence of productivities according to the mechanism described in section one. Thus, the lag of the non-innovative branch of the less innovative capitalist economy is equal to that of the innovative branch of this same non-innovative capitalist economy in relation to the respective branches of the innovative economy. So the homogeneity of differences in productivity is the consequence of high levels of employment.

Let us now take Ricardo's (195I: 135-I4I) example, but we substitute England and Portugal with Germany and Singapore, textiles and wine with automobiles and microelectronics. Even if Germany is initially superior in the production of microelectronics, Singapore specializes on microelectronics, because Germany's advance in automobiles is higher than in microelectronics. If technical progress is linked to learning by doing, then a leading economy will have higher productivity advances in established branches, where it already dominates, in relation to newly emerging branches, where a catch-up economy and a technically leading economy start production at the same time. Germany's overtaking Britain between 1890 and 1960 (Kindleberger 1975: 482; Aukrust 1964: 32) or Britain's overtaking France during the Industrial Revolution (Crafts 1989: 427) demonstrate the possibility of a TAC being locked into old production lines. The mobility of knowledge only adds to this possibility of a TBC catching up and overtaking a TAC, 
as it puts catch-up economies on a more equal footing with the leading economy with respect to start-ups in new branches.

Wage restraint in the TACs is one strategy that is followed. It is ineffective, however, because the low costs of labor in catch-up TBCs are not the result of their low wages, but of subsidies (which do not violate WTO regulations) to their export sectors in the form of low international prices of locally produced wage goods. As the devaluation-driven industrializing country can contribute only little to balancing world production and world consumption, the TACs should absorb the additional production arising from the catch-up economies' voluntary acceptance of unequal exchange and expand consumption. The demand of an appreciation of the Chinese Yuan made by the Western countries in late 2003 is just an illustration of this point.

The second solution is industrial policy involving the mobilization of resources for investment without control of the market. The guiding star of investment is not the shortterm profit rate, but an expected profit rate resulting from discussions and negotiations between bureaucrats and industrialists, who benefit at least in the short run by means of subsidies and protection. Industrial policies weaken the relative autonomy of the economy with respect to the political sphere, in the West as well. The two homogeneous classes of a capitalist economy become fragmented. Part of the labor force and some capitalists become interested in this industrial policy. The characteristically simple political structure of a lean capitalist state and the large range of autonomous activities offered by a civil society give way to a complicated scenario of power games.

\section{Rent is inevitable, the ways of dealing with it varied}

The analysis of export-led growth and globalization shows that not only import substitution, but any development policy is confronted with the challenge of dealing with rent. In its pure form, export-oriented industrialization consists of subsidizing additional export workers from the agricultural rent. The highly interventionist state of the successful export-oriented industrializing countries of East and Southeast Asia has its basis in the high losses of foreign exchange involved in such a strategy, as opposed to a mix between devaluation and subsidy-based industrial policies (Wade I993; Deyo I98I: 78).

Once full employment is reached it seems to take about ten years for a militant working class to emerge and contribute to the accelerated expansion of the internal market so that, in turn, small and medium-sized industries can emerge (Lee 1989), even with government protection for large monopolistic enterprises. Korea shows that without reforming the state, especially the administration responsible for economic policy, these enterprises cannot enjoy conditions equal to those of large enterprises (Kim I999).

The challenge of globalization consists in enabling the catching-up economies to rapidly reach high levels of employment. Additional exports of manufacturers are themselves not sufficient to reach this goal. 
Export-oriented industrialization has been successful in overcoming underdevelopment - with the exception of small city-states - only in countries, where agricultural reforms were implemented (Kim 1976). Agricultural reforms involve a redistribution of land (Taiwan and South Korea) or new settlements (with terrible ecological consequences, e.g., in Thailand (Trébouil 1993: 365-368). Higher rural mass incomes are advantageous for privatization and liberalization, as they create a market for small-scale industry (Dutt I991: 348; Adelman 1984: 938-944), as shown in mainland China (Ross 1994). Agricultural reforms integrate marginal labor time into the labor process of the owner-operated farm. The family farm can achieve high yields by using only a part of its labor, but this income is not sufficient for survival. Additional, much less productive labor therefore has to be supplied (which was not employed prior to land redistribution, because its additional product was lower than its costs, see Elsenhans I979: 552-562). Farmers who own their farms will not consider the additional consumption necessary for survival as costs, and will therefore maximize production as long as better earning opportunities do not exist outside of the agricultural sector. A side effect of this is very low wages for non-agricultural by-employment in rural areas (Dasgupta/Ray 1987: 179), as labor prices correspond to its low marginal product on small, land-scarce farms. The agricultural rent often subsidizes export production, as in the case of young female workers in East Asian export production.

The economic growth promoted by NGOs involves channeling resources to the marginal population. NGOs support and sometimes strengthen the poor at the economic and political levels, selling "entitlements to moral well-being" (Elsenhans I99ra), which the privileged local strata and the privileged societies of the West are willing to purchase. There is growing disillusionment with the bureaucratization of these organizations. The increasing dominance of their middle-class perspectives (Jain 1995: 63) has led some authors to talk about a cyclical pattern with respect to NGOs: from charismatic mobilization to bureaucratization and decline, until a new charismatic leader eventually emerges (Avina I993: 470). The economic basis of NGOs is basically not different from the economic basis of the more idealistically-minded members of the state classes, from which Sklar expected the same dynamic behavior as contemporary supporters of NGOs (Sklar 1967: 8). This economic basis consists of a rent acquired from rentiers in their own societies and at the international level. The widely-held view that their tendencies towards bureaucratization can be mitigated by appropriate organizational arrangements, such as participation, is once more based on the Weberian theoretical perspective, which maintains that forms of interaction create norms without necessarily being dependent on an economic basis. Recent literature about participation has underscored the tendencies towards authoritarianism and bureaucratization (Cleaver I999: 597-6I2).

All the strategies mentioned here, from import substitution to NGO promotion, have two characteristics in common: first, that there is some sort of guidance and support to investment from the non-market sphere; and, second, a certain improvement in the standard of living of the poor, which implies an expansion of the mass market. Im- 
ported investment goods in import-substituting industrialization create fewer jobs than export-oriented industrialization. But this strategy is not viable for absorbing the global surplus of marginal labor in the South, because export markets in the industrialized West are too limited (Elsenhans I98I; Cline 1982). Agricultural reforms reduce the potential surplus available for investment, just as NGOs collecting donations do. However, they do increase the incentives for investment in a variety of ways, especially via the increased demand of the poor for simple products, which can be produced locally, even using locally produced investment goods.

Thus, all of the development strategies analyzed here involve mechanisms of redistribution, which aim at surplus reduction in favor of consumption in order to increase the efficiency of investment. A more egalitarian distribution of income reduces the capitaloutput ratio and therefore leads to a higher growth rate despite possibly lower investment (Strassmann 1956; Murphy 1989; Dopfer 1979: 222).

Such strategies of reducing rents in favor of consumption by the poor, implying a higher efficiency in investment, played an important role historically in Europe's transition to capitalism, as I have shown in my analysis of the English poor laws, a subsidy paid to the poor out of land taxes, a part of the rent (Elsenhans 1992)

This form of rent redistribution in favor of employment is even possible within the framework of the current foreign assistance regime. Donors could create an artificial industry which would create employment without competing with labor in their countries (Elsenhans I99Ib: 28I-283). They could create easily identifiable stones, which could be imitated only at very high costs. The stones would be thrown from helicopters into remote areas of the country to be gathered by marginal laborers. The donors would announce the establishment of purchasing agencies in the more centrally located areas of the country concerned and would purchase these stones at prices corresponding to the subsistence costs of a stone gatherer plus the costs of transport from the local market to the purchasing agency. The marginal population - and only this population - would gather these stones, which they would then sell on local markets in order mostly to buy food. At appropriately low exchange rates, this food will increasingly be supplied by local farmers, who invest in order to increase their production, especially their yields, and use as much locally produced investment goods and additional labor as possible. The market for small and medium-sized industry grows with further employment, depending on the scarcity of labor. The collected stones could then be thrown again from helicopters into remote areas of the country. The annual incomes of one billion marginal laborers and their dependents could be uplifted from about \$ I5O to \$225 by means of such an artificial industry with slightly more financial assistance than currently provided by international donors and about double the transfers from West to East Germany, which have not created inflation. There would also not be a problem of local inflation, as the additional purchasing power has its counterpart in convertible currency. At appropriately low exchange rates, the inflow of this money will not cause local agriculture to be undercut, as in the case of cheap food imports, but will create additional import capacity for economic diversification. The additional purchasing power would create incentives 
for local producers to enter wage-goods production, so that the rigidity of supply would gradually be overcome.

Such a process is sustainable not because the artificial industry would supply marketable products, but because it would create growth incentives in the rest of the economy on the basis of the capitalist growth mechanism and succeed in overcoming underdevelopment by increasing mass demand, investment, productivity and production.

The process differs from current development aid in the following points. It will no longer be the planner, nor the staff of development agencies paid from development assistance, but the automatism of the market fed by payments to the poor, which determines investment priorities. There is not even a need to define what legitimate basic needs are, because the marginal population indicates through its purchasing decisions, without any administrative costs to producers, what should be produced.

The main losers of a reorientation of development assistance are the development assistance bureaucracies, especially in the donor countries. These would have to transform themselves into competitive suppliers of appropriate technology for products to be produced in the aid receiving countries.

Measures in the non-market economy in support of mass consumption and investment in order to launch the process of capitalist growth are characterized by decreasing returns. Import substitution becomes more inefficient the more it is followed. Agrarian reforms threaten property rights and have to be carefully designed to avoid the collusion of propertied interests against the planning state carrying out these reforms. NGOs themselves become larger and more bureaucratized if they are entrusted with more important tasks. The absorptive capacity of the external market limits export-oriented industrialization. My less-than-ideal solution has the advantage of combining the market mechanism with demand creation to the greatest possible degree without creating unlimited cut-throat competition between labor in devaluation-driven industrializing economies and labor in the more developed capitalist economies.

\section{I2. Perspectives}

This article has certain implications, which may arouse suspicion and opposition. The model disagrees with mainstream economics, but not with the perspectives of society, which mainstream economics claims to promote. In mainstream economics, the market is considered the most efficient instrument both for allocating resources and for controlling the inevitable emergence of rent-seeking elites through the instrument of competition. My model disagrees, in line with a Keynesian perspective, with the neoclassical mainstream on the motivations of entrepreneurs to invest resources and, in line with neoclassical new endogenous growth theory, considers the process of economic growth to be a giant learning process among the great mass of producers, which can take on a variety of patterns, from formal education to learning by doing in the production process. It 
shares the argument with most forms of neoclassical endogenous growth theory on the relative unimportance of a rise in the share of investment in national income versus the importance of technical progress.

My model does not include a cultural critique of consumer society. The implied argument is that people themselves know best what they should consume. There are many needs, which are satisfied neither by society nor by the economy, but only through community. As long as paid labor is the main source of income for the mass of the population and, hence, also the main mechanism of social integration, a society requires a labor market that does not make labor bear the full burden of the risks inherent to technological change and changes in the product mix. A high marginal product, a clear commitment to full employment policies, labor laws, which facilitate mobility through subsidies, compensation for unemployment, and so forth are reasonable measures for empowering labor and making labor flexible in developed countries.

The essential and defining characteristic of underdevelopment is the absence of the condition for full employment in underdeveloped economies. Development is therefore nothing else than a mix of measures for a rise in the employment level via an increase in the marginal product of labor, i.e., in essence, rising mass incomes.

My model's principal opposition to mainstream development economics is in the priority I give to mass consumption over investment. Mass consumption will pull investment provided that the growth in mass consumption is kept in line with the technical possibilities for productivity growth. It is obvious that the technical possibilities in an underdeveloped economy can be enhanced by supportive means from the non-market economy. Yet such supportive measures always lend themselves to manipulating the market in favor of rent-seeking interests.

Development could then be thought of as the art of using a variety of non-market structures, including foreign assistance and sectoral planning, to allow the mechanism of competition to evolve - to the benefit of labor and against the interests of rentiers - by making labor scarce. The rich would therefore be able to maintain their economic position only through the profitable use of labor. In a society with rising mass incomes, the profitable use of labor depends on the extent to which mass markets are supplied with new products. Expanding mass markets create the basis for overall profit. An orientation towards market demand is the basis of the competitive advantage sought by enterprises in order to secure their share of the profit.

Development policy therefore leads to the welfare state, which is rooted in the historical transition to capitalism. If labor had not been able to bargain its services to the rich and reduce the available surplus to the amount necessary for financing investment, the danger of a rentier society would have proved insurmountable.

\section{References}

Adelman, Irma (1984): Beyond Export-led Growth, in: World Development, I2, 9 (September), pp. 937-949 
Adelman, Irma (200I): Fallacies in Development Theory and Their Implications for Policy, in: Meier, Gerald M.; Stiglitz, Joseph E. (eds.): Frontiers of Development Economics. The Future in Perspective (New York: Oxford University Press), pp. I03-I34.

Aitken, Brian; Hanison, Aun; Lipsey, Robert E. (1996): Wages and Foreign Ownership. A Comparative Study of Mexico, Venezuela and the United States, in: Journal of International Economics, 40, 3/4 (May), pp. 345-37I

Albertini, Jean Marie; Auvolat, M.; Lerouge, F. (1967): Les mécanismes du sous-développement (Paris: Les Editions ouvrières)

Allub, Leopoldo (1983): Heterogeneidad estructural, disigualdad social y privación relativa en regiones petroleras, in: Revista Mexicana de Sociología, 45, I (January - March), pp. 169-190

Amsden, Alice H. (1989): Asia’s Next Giant (New York; Oxford: Oxford University Press)

Ark, Bart van; Pilat, Dirk (1993): Productivity Levels in Germany, Japan, and the United States: Differences and Causes, in: Brookings Papers on Economic Activity, 2, pp. I69

Aukrust, Odd (1964): Factors of Economic Development: A Review of Recent Research, in: Weltwirtschaftliches Archiv, 93, 2, pp. 23-43

Apter, David Ernest (1969): The Politics of Modernization (Chicago, Ill. et al.: University of Chicago Press)

Auty, Richard M. (1994): Industrial Policy Reform in Six Large Newly Industrializing Countries: The Resource Curse Thesis, in: World Development, 22, I (January), pp. II-26

Avina, Jeffrey (1993): The Evolutionary Life Cycles of Non-governmental Development Organisations, in: Public Administration and Development, I3, 5 (December), pp. 453-474

Baer, Werner; Hervé, Michel E.A. (1966): Employment and Industrialisation in Developing Countries, in: Quarterly Journal of Economics, 80, I (February), pp. 89-107

Baer, Werner; Miles, William R.; Moran, Alan B. (1999): The End of the Asian Myth: Why Were the Experts Fooled, in: World Development, 27, Io (October), pp. 1735-1747

Bagchi, Amiya Kumar (1972): Private Investment in India 1900-1938 (Cambridge: Cambridge University Press)

Bai, Moo-Ki (1982): The Turning Point in the Korean Economy, in: Developing Economies, 20, I (March), pp. II7-I40

Bauer, Peter Tamás (198I): Equality, the Third World and Economic Delusion (Cambridge, Mass.: Harvard University Press)

Bauer, Peter Tamás; Yamey, Basil S. (I968): Markets, Market Control and Marketing Reform. Selected Papers (London: Weidenfeld \& Nicolson)

Bayart, Jean-François (1989): L'Etat en Afrique (Paris: Fayard)

Beblawi, Hazem; Luciani, Giacomo (1987): The Rentier State (London: Croom Helm)

Behrendt, Richard F. (197I): Die Zukunft der Entwicklungsländer als Problem des Spätmarxismus, in: Bohnet, Michael (ed.): Das Nord-Süd-Problem. Konflikte zwischen Industrie- und Entwicklungsländern (Munich: Piper), pp. 86-IoI

Benetti, Carlo (1974): L'accumulation dans les pays capitalistes sous-développées (Paris: Anthropos) 
Bernanke, Ben S.; Carey, Kevin (1996): Nominal Wage Stickiness and Aggregate Supply in the Great Depression, in: Quarterly Journal of Economics, III, 3 (August), pp. 853-883

Boatler, Robert W. (1974): Las predicciones de la teoría del comercio internacional y el crecimiento de las exportaciones manufacturadas de México, in: El Trimestre Económico, 4I, I64 (October - December), pp. 8II-857

Bratton, Michael; Van de Walle, Nicholas (1994): Neopatrimonial Regimes and Transitions in Africa, in: World Politics, 46, 4 (June), pp. 453-489

Brown, Kenneth D. (1982): The English Labour Movement I700-I95I (New York: Palgrave MacMillan)

Bruton, Henry J. (1968): Import Substitution and Productivity Growth, in: Journal of Development Studies, 4, 3 (April), pp. 306-326

Chakravarty, Sukhamoy (1987): The State of Development Economics, in: Manchester School of Economic and Social Studies, 55, 2 (June), pp. I25-I43

Chao, Kang (1986): Man and Land in Chinese History (Stanford, Cal.: Stanford University Press)

Chen, Haichun; Gordon, M. J.; Yan, Zhiming (1994): The Real Income and Consumption of an Urban Chinese Family, in: Journal of Development Studies, 3I, I (October), pp. 2OI-2I3

Clague, Christopher K. (1967): An International Comparison of Industrial Efficiency: Peru and the United States, in: Review of Economics and Statistics, 49, 4 (November), pp. $487-493$

Clague, Christopher (199I): Relative Efficiency, Self-Containment and Comparative Costs of Less Developed Countries, in: Economic Development and Cultural Change, 39, 2 (April), pp. 506-530

Cleaver, Frances (1999): Paradoxes of Participation: Questioning Participatory Approaches to Development, in: Journal of International Development, II, 4 (June), pp. 597-6I2

Cline, William (1982): Can the East Asian Model of Development Be Generalized?, in: World Development, IO, 2 (February), pp. 8I-90

Collins, Susan M.; Bosworth, Barry P. (1996): Economic Growth in East Asia: Accumulation versus Assimilation, in: Brookings Papers on Economic Activity, 2, pp. 135-203

Corden, W. Max; Neary, J. Peter (1982): Booming Sector and De-Industrialization in a Small Open Economy, in: Economic Journal, 92, 368 (December), pp. 825-848

Crafts, Nicholas F. R. (1989): British Industrialization in an International Context, in: Journal of Interdisciplinary History, 19, 3 (Winter), pp. 415-428

Dandekar, V.M. (1962): Economic Theory and Agrarian Reform, in: Oxford Economic Papers, I4, I (February), pp. 69-80

Dasgupta, Partha; Ray, Debraj (1987): Inequality as a Determinant of Malnutrition and Unemployment, in: Economic Journal, 97, 385 (March), pp. 176-188

Denison, Edward F. (1967): Sources of Postwar Growth in Nine Western Countries, in: American Economic Review, 57, 2 (May), pp. 325-332

Deyo, Frederick C. (198I): Dependent Development and Industrial Order. An Asian Case Study (New York: Praeger) 
Dopfer, Kurt (1979): The New Political Economy of Development. Integrated Theory and Asian Experience (New York: St. Martin's Press)

Dornbos, Martin (1990): The African State in Academic Debate: Retrospect and Prospect, in: Journal of Modern African Studies, 28, 2, pp. 179-198

Dutt, Amitava Krishna (I99I): Stagnation, Income Distribution and the Agrarian Constraint: A Note, in: Cambridge Journal of Economics, I5, 3 (September), pp. 343-35I

Elsenhans, Hartmut (1979): Agrarverfassung, Akkumulationsprozeß, Demokratisierung, in: Elsenhans, Hartmut (ed.): Agrarreform in der Dritten Welt (Frankfurt on the Main; New York: Campus), pp. 505-652

Elsenhans, Hartmut (198I): Social Consequences of the NIEO. Structural Change in the Periphery as Precondition for Continual Reforms in the Centre, in: Jahn, Egbert/ Sakamoto, Yoshikazu (eds.): Elements of World Instability: Armaments, Communication, Food, International Division of Labour. Proceedings of the Eighth International Peace Research Association Conference (Frankfurt on the Main; New York: Campus), pp. 86-95

Elsenhans, Hartmut (1983): Rising Mass Incomes as a Condition of Capitalist Growth: Implications for the World Economy, in: International Organization, 37, I (Winter), S. $\mathrm{I}-38$

Elsenhans, Hartmut (1991a): Political Obstacles to Private Sector Development, in: Bennett, James G. (ed.): Private Sector Development in Bangladesh (Cologne: Oase), pp. 205-245 Elsenhans, Hartmut (I99Ib): Problems Central to Economic Policy Deregulation in Bangladesh, in: Internationales Asienforum, 22, 3/4 (November), pp. 259-286

Elsenhans, Hartmut (1992): English Poor Law and Egalitarian Agrarian Reform in the Third World, in: Elsenhans, Hartmut (ed.): Equality and Development (Dhaka: Center for Social Studies), pp. I30-162

Elsenhans, Hartmut (1994): Rent, State and the Market: »The Political Economy of the Transition to Self-sustained Capitalism«, in: Pakistan Development Review, 33, 4 (December), pp. 393-428

Elsenhans, Hartmut (1996): State, Class and Development (New Delhi: Radiant Publishers) Elsenhans, Hartmut (1999a): Autonomy of Civil Society, Empowerment of Labour, and the Transition to Capitalism, in: Jain, Randhir B.; Khator, Renu (eds.): Bureaucracy Citizen Interface: Conflict and Consensus (New Delhi: B.R. Publishing Corporation), pp. I5-60

Elsenhans, Hartmut (1999b): Globalization or Dutch Disease: Its Political and Social Consequences, in: Singer, Hans Wolfgang/Hatti, Neelambar/Tandon, Rameshwar (eds.): Technological Diffusion in Third World. New World Order Series, Volume I6 (Part-I) (New Delhi: B.R. Publishing Corporation), pp. 438-44I

Fagerberg, Jan (2000): Technological Progress, Structural Change and Productivity Growth: A Comparative Study, in: Structural Change and Economic Dynamics, II, 4, pp. 393-4II

Falola, Toyin (1996): Development Planning and Decolonization in Nigeria (Gainesville, Fla.: University Press of Florida) 
Geary, Dick (198I): European Labour Protest (London: Croom Helm)

Georgescu-Roegen, Nicholas (1960): Economic Theory and Agrarian Economics, in: Oxford Economic Papers, I2, I (February), pp. 32-40

Germani, Gino (I966): Politica y sociedad en una epoca de transición. De la sociedad tradicional a la sociedad de masas (Buenos Aires: Editorial Paidos)

Goode, Richard (1984): Government and Finance in Developing Countries (Washington: Brookings Institution)

Grabowski, Richard (1999): Pathways to Economic Development (Cheltenham: Elgar)

Grabowski, Richard (2000): Integrated National Markets, Industrialization, and Broadly Based Agricultural Growth, in: Asien-Afrika-Lateinamerika, 28, 3, pp. 24I-264

Guillaumont-Jeanneney, Sylviane; Hua, Ping (1996): Politique du change et développement des exportations manufacturées en Chine, in: Revue économique, 47, 3 (May), pp. $85 \mathrm{I}-860$

Habakkuk, Hrothgar J. (1972): Fluctuations and Growth in the I9th Century, in: Robertson, H. M.; Kooy, M. (eds.): Studies in Economics and Economic History (London: Macmillan), pp. 259-279

Hagen, Everett E. (1964): On the Theory of Social Change. How Economic Growth Begins (London: Tavistock)

Haggard, Stephan Mark (1983): Pathways from the Periphery: The Newly Industrializing Countries in the International System (Berkeley, Cal.: Dissertation)

Harrison, Lawrence E. (1985): Underdevelopment is a State of Mind - The Latin American Case (Boston, Mass.; London: University Press of America)

Hayami, Yujiro (1997): Development Economics: From the Poverty to the Wealth of Nations (Oxford: Oxford University Press)

Heintz, Peter (1969): Ein soziologisches Paradigma der Entwicklung (Stuttgart: Ferdinand Enke)

Hemmer, Hans-Rimbert (1978): Wirtschaftsprobleme der Entwicklungsländer (Munich: Vahlen)

Hiemenz, Ulrich (1989): Development Strategies and Foreign Aid Policies for Low Income Countries in the I990s (Kiel: Institut für Weltwirtschaft)

Hirschman, Albert O. (1971): A Bias for Hope. Essays on Development and Latin America (New Haven, Conn.; London: Yale University Press)

Hofmann, Michael (200I): Neue Wege der Entwicklungszusammenarbeit durch die Trendsetter der Geberzusammenarbeit, in: Asien-Afrika-Lateinamerika, 29, 5, pp. 4I7-439

Hohorst, Gerd (1973): Bevölkerungsentwicklung und Wirtschaftswachstum als historischer Entwicklungsprozess demo-ökonomischer Systeme, in: Mackensen, Rainer; Wewer, Heinz (eds.): Dynamik der Bevölkerungsentwicklung. Strukturen - Bedingungen Folgen (Munich: Hanser), pp. 9I-II8

Holtgrave, Wilfried (1987): Industrialisierung in Singapur. Chancen und Risiken industrieorientierter Spezialisierung (Frankfurt on the Main; New York: Campus)

Ibn Khaldûn, Abd-al-Rahman (1967): Discours sur l'Histoire universelle. Al-Muqaddima. Traduction nouvelle, préface et notes par Vincent Monteil (Paris: Sindbad) 
Jain, Randhir B. (1995): Influencing Public Choices: Challenges to NGOs in India, in: Jain, Randhir B. (ed.): NGOs in Development Perspective (New Delhi: Friedrich-EbertStiftung), pp. 55-79

Joseph, Richard A. (1987): Democracy and Prebendial Politics in Nigeria: The Rise and Fall of the Second Republic. African Studies Series, No. 56 (Cambridge: Cambridge University Press)

Kalecki, Michal (197I): Selected Essays on the Dynamics of the Capitalist Economy 1933-1970 (Cambridge: Cambridge University Press)

Kamas, Linda (1986): Dutch Disease Economics and the Colombian Export Boom, in: World Development, I4, 9 (September), pp. II77-II98

Keynes, John Maynard (1973): The General Theory of Employment, Interest and Money. The Collected Writings of John Maynard Keynes (London: Macmillan)

Khan, Mohammad Irshad (1963): A Note on Consumption Patterns in the Rural Areas of East Pakistan, in: Pakistan Development Review, 3, 3 (Autumn), pp. 399-4I3

Khan, Mushtaque H. (200o): Rents, Efficiency and Growth, in: Khan, Mushtaq H.; Jomo, Kwame Sundaram (eds.): Rents, Rent-Seeking and Economic Development. Theory and Evidence in Asia (Cambridge et al.: Cambridge University Press), pp. 2I-69

Kim, Douglas (1976): Small Farmer Economy and Development Policy with Special Reference to Korea, in: Asian Economies, 5, I9 (December), pp. 5-22

Kim, Hong Joo (1999): Kanalisierung von Renten und Transitionsproblematik - am Beispiel der Republik Korea, in: Zinecker, Heidrun (ed.): Unvollendete Demokratisierung in Nichtmarktökonomien. Die Blackbox zwischen Staat und Wirtschaft in den Transitionsländern des Südens und Ostens (Amsterdam: G+B Verlag Fakultas), pp. 5770

Kindleberger, Charles P. (1975): Germany's Overtaking of England I806-1914 (2), in: Weltwirtschaftliches Archiv, III, 3, pp. 477-504

Lafay, Gérard (1995): La compétitivité européenne face au durcissement de la concurrence internationale, in: Revue économique, 46, 3 (May), pp. 679-689

Lal, Deepak (1983): The Poverty of 'Development Economics' (Lancing: Institute of Economic Affairs)

Leach, E.R. (1954): Political Systems of Highland Burma. A Study of Kachin Social Structure (London: G. Bell \& Sons)

Lee, Won-Young (1989): Role of Small and Medium-Sized Enterprises of Industrialized Countries in the Transfer of Technology to the Republic of Korea, in: Asian Economies, 18, 69 (June), pp. 40-69

Lipset, Seymour Martin (1986): Values, Education, and Entrepreneurship, in: Bossert, Thomas; Klaren, Peter (eds.): Promise of Development - Theories of Change in Latin America (Boulder, Colo.; London: Westview), pp. 39-75

Lucas, Robert E. (1988): On the Mechanics of Economic Development, in: Journal of Monetary Economics, 22, I (March), pp. 3-42

MacClelland, David; Winter, Sarah K. (1969): Motivating Economic Achievement (New York; London: The Free Press Macmillan) 
Mahon, James E. (1992): Was Latin America Too Rich to Prosper? Structural and Political Obstacles to Export-Led Industrial Growth, in: Journal of Development Studies, 28, 2 (January), pp. 24I-263

Marcussen, Henrik Secher (1983): The Ivory Coast Facing the Economic Crisis, in: Carlsson, Jerker (ed.): Recession in Africa (Uddevalla: Scandinavian Institute of African Studies), pp. I-27

Marx, Karl (2000): Grundrisse der politischen Ökonomie (Frankfurt on the Main: Europäische Verlagsanstalt)

Mathur, Purushottam Narayan (1991): Why Developing Countries Fail to Develop (London: Macmillan)

Meier, Gerald M. (1984): Emerging from Poverty. The Economics that Really Matters (New York: Oxford University Press)

Minami, Ryoshin (1966): A Model of Economic Development from Classical to Neoclassical Stages, in: Weltwirtschaftliches Archiv, 97, 2, pp. 345-355

Ministère de la Planification et de l'Aménagement du Territoire (MPAT) (I980): Synthèse du bilan économique et social de la décennie 1967-1978 (Algiers)

Murphy, Kevin M.; Shleifer, Andrei; Vishny, Robert (1989): Income Distribution, Market Size and Industrialization, in: Quarterly Journal of Economics, IO4, 3 (August), pp. 537564

Mytelka, Lynn Krieger (1986): The Transfer of Technology: Myth or Reality?, in: Cosgrove, Carol; Jamar, J. (eds.): The European Community's Development Policy: The Strategies Ahead. Conference organised at the College of Europe, Bruges, 4-6 July I985 (Brugge: De Tempel), pp. 243-28I

Neale, Walter C. (1957): Reciprocity and Redistribution in the Indian Village: Sequal to Some Notable Discussion, in: Polanyi, Karl; Arensberg, Conrad M.; Pearson, Harry W. (eds.): Trade and Markets in the Early Empires (New York; London: Free Press; Collier Macmillan), pp. 218-238

Nef, John U. (1958): Cultural Foundations of Industrial Civilization (Cambridge: Cambridge University Press)

Nelson, Richard R. (1956): A Theory of Low-Level Equilibirum Trap in Underdeveloped Economies, in: American Economic Review, 46, 5 (December), pp. 894-908

Nohlen, Dieter; Sturm, Roland (1982): Über das Konzept der strukturellen Heterogenität, in: Nohlen, Dieter/Nuscheler, Franz (eds.): Handbuch der Dritten Welt (I): Unterentwicklung und Entwicklung - Theorien, Strategien, Indikatoren (Hamburg: Hoffmann \& Campe), pp. 92-II6

O’Brien, Philip(I975): A Critique of Latin American Theory of Dependency, in: Oxaal, Ivar; Barnett, Tony; Booth, David (eds.): Beyond the Sociology of Development (London; Boston, Mass.: Routledge \& Kegan Paul), pp. 7-25

Oki, Akira (1984): The Dynamics of Subsistence Economy in West Sumatra, in: Turton, Andrew; Tanabe, Shigeharu (eds.): History and Peasant Consciousness in South East Asia. SENRI Ethnological Studies, No. I3 (Osaka: National Museum of Ethnology), pp. 267-29I 
Page, John et al. (1993): The East Asian Miracle. Economic Growth and Public Policy (Washington: World Bank)

Palma, Gabriel (1978): Dependency: A Formal Theory of Underdevelopment or a Methodology for the Analysis of Concrete Situations of Underdevelopment, in: World Development, 6, 7/8 (July - August), pp. 88I-924

Pieterse, Jan Nederveen (1996): The Development of Development Theory: Towards Critical Globalism, in: Review of International Political Economy, 3, 4, pp. 54I-564

Posner, M.V. (196I): International Trade and Technical Change, in: Oxford Economic Papers, I3, 3 (October), pp. 323-342

Ramos, Joseph (1974): A Heterodoxical Interpretation of the Employment Problem in Latin America, in: World Development, 2, 7 (July), pp. 47-58

Ray, Ranyan (2000): Poverty and Expenditure Pattern of Households in Pakistan and South Africa: A Comparative Study, in: Journal of International Development, I2, 2 (March), pp. $24 \mathrm{I}-256$

Reischauer, Edwin O.; Fairbank, John K. (1960): East Asia. The Great Tradition (Boston, Mass.: Houghton Mifflin)

Rhee, Jong-Chan (1994): The State and the Industry in South Korea. The Limits of the Authoritarian State (London: Routledge)

Ricardo, David (I95I): On the Principles of Political Economy and Taxation. The Works and Correspondence of David Ricardo (I) (Cambridge et al.: Cambridge University Press)

Rieger, Hans Christoph (199I): Die wirtschaftliche Entwicklungsstrategie Singapurs. Erfolge und Politische Implikationen, in: Draguhn, Werner (ed.): Asiens Schwellenländer: Dritte Weltwirtschaftsregion? Wirtschaftsentwicklung und Politik der ,Vier kleinen Tiger sowie Thailand, Malaysia und Indonesien (Hamburg: Institut für Asienkunde), pp. $15-32$

Rodegem, F. (1974): La fonction hyperphatique du langage, in: Cultures et développement, 6, 2, pp. 277-304

Rosenstein-Rodan, P.N. (1943): Problems of Industrialization of Eastern and South Eastern Europe, in: Economic Journal, 53, 210 (June - September), pp. 202-2II

Ross, John (1994): Economic Reform - Success in China - Failure in Eastern Europe, in: Monthly Review, 46, I (May), pp. 19-25

Rostow, Walt Whitman (197I): The Take-off into Self-sustained Growth, in: Mountjoy, Alan B. (ed.): Developing the Underdeveloped Countries (London: Macmillan), pp. 86II 4

Sanchez Ayuso, Manuel (1972): Quelques réflexions sur l'industrialisation et le commerce extérieur dans les pays en voie de développement, in: Economie appliquée, 25, I (January - March), pp. II3-I24

Say, Jean-Baptiste (1972): Traité d'économie politique (Paris: Calmann-Lévy)

Schmid, Claudia (199I): Das Konzept des Rentier-Staates. Ein sozialwissenschaftliches Paradigma zur Analyse von Entwicklungsgesellschaften und seine Beziehungen für den Vorderen Orient (Hamburg: Lit) 
Sen, Amartya Kumar (1966): Peasants and Dualism with or without Surplus Labour, in: Journal of Political Economy, 74, 5 (October), pp. 427-450

Sen, Amartya Kumar (198I): Poverty and Famines. An Essay on Entitlement and Deprivation (Oxford: Clarendon)

Singer, Hans Wolfgang (1950): U.S. Foreign Investment in Underdeveloped Areas. The Distribution of Gains between Investing and Borrowing Countries, in: American Economic Review, 40, 2 (May), pp. 473-485

Singer, Hans Wolfgang (1975): The Distribution of Gains from Trade and Investment Revisited, in: Journal of Development Studies, II, 4 (July), pp. 376-382

Skinner, G. William (1971): Chinese Peasants and the Closed Community: An Open and Shut Case, in: Comparative Studies in Society and History, I3, 3 (July), pp. 270-28I

Sklar, Richard L. (1967): Political Science and National Integration - A Radical Approach, in: Journal of Modern African Studies, 5, I, pp. I-II

Smith, Adam (1976): The Wealth of Nations (Oxford: Clarendon Press)

Strassmann, W. Paul (1956): Economic Growth and Income Distribution, in: Quarterly Journal of Economics, 70, 3 (August), pp. 425-440

Tönnies, Ferdinand (I935): Gemeinschaft und Gesellschaft: Grundbegriffe der reinen Soziologie (Berlin: Curtius)

Toye, John (1987): Dilemmas of Development. Reflections on the Counter-Revolution in Development Theory and Policy (Oxford: Basil Blackwell)

Trébouil, Guy (1993): Agriculture pionnière, révolution verte et dégradation de l'environnement en Thailande: Le cinquième dragon ne sera pas vert, in: Tiers Monde, 34, I34 (April - June), pp. 365-384

Usher, Dan (1989): The Dynastic Cycle and the Stationary State, in: American Economic Review, 79, 4 (December), pp. I03I-IO44

Wade, Robert (1993): The Visible Hand: The State and East Asia's Economic Growth, in: Current History, 93, 578, pp. 43I-440

Wakeman, Frederic (1977): Rebellion and Revolution: The Study of Popular Movements in Chinese History, in: Journal of Asian Studies, 36, 2 (February), pp. 20I-237

Wittfogel, Karl August (193I): Wirtschaft und Gesellschaft Chinas. Versuch der wissenschaftlichen Analyse einer großen asiatischen Agrargesellschaft (Leipzig: C. L. Hirschfeld)

Wittfogel, Karl August (1957): Oriental Despotism. A Comparative Study of Total Power (New Haven, Conn. et al.: Yale University Press)

Yates, Douglas (1996): The Rentier State in Afrika. Oil Rent Dependency and Neocolonialism in the Republic of Gabon (Asmara: Trenton) 
